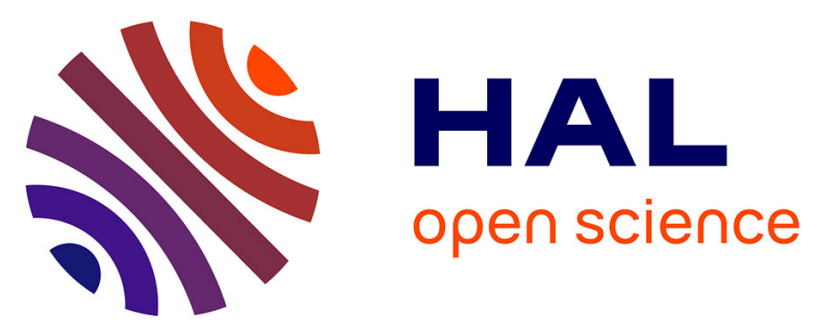

\title{
TOWARDS INTEGRATING MOOC IN THE MOROCCAN HIGHER EDUCATIONAL SYSTEM: ECONOMIC PEDAGOGICAL MODEL BASED ON ICT FOR ON-GOING EDUCATION AND TEACHER MOTIVATION
}

Bouchaib Riyami, Khalifa Mansouri, Franck Poirier

\section{To cite this version:}

Bouchaib Riyami, Khalifa Mansouri, Franck Poirier. TOWARDS INTEGRATING MOOC IN THE MOROCCAN HIGHER EDUCATIONAL SYSTEM: ECONOMIC PEDAGOGICAL MODEL BASED ON ICT FOR ON-GOING EDUCATION AND TEACHER MOTIVATION. ICERI 2016, Nov 2016, Seville, Spain. pp.6867 - 6873, 10.21125/iceri.2016.0572 . halshs-01427410

\author{
HAL Id: halshs-01427410 \\ https://shs.hal.science/halshs-01427410
}

Submitted on 5 Jan 2017

HAL is a multi-disciplinary open access archive for the deposit and dissemination of scientific research documents, whether they are published or not. The documents may come from teaching and research institutions in France or abroad, or from public or private research centers.
L'archive ouverte pluridisciplinaire HAL, est destinée au dépôt et à la diffusion de documents scientifiques de niveau recherche, publiés ou non, émanant des établissements d'enseignement et de recherche français ou étrangers, des laboratoires publics ou privés. 


\title{
TOWARDS INTEGRATING MOOC IN THE MOROCCAN HIGHER EDUCATIONAL SYSTEM: ECONOMIC PEDAGOGICAL MODEL BASED ON ICT FOR ON-GOING EDUCATION AND TEACHER MOTIVATION
}

\author{
Bouchaib Riyami $^{1,2}$, Khalifa Mansouri ${ }^{2}$ et Franck Poirier ${ }^{1}$ \\ ${ }^{1}$ Lab-STICC, Université Bretage Sud, Vannes, France \\ ${ }^{2}$ Lab-SSDIA Signaux, Systèmes Distribués et Intelligence Artificielle, Université Hassan II de \\ Casablanca, Maroc \\ b.riyami@gmail.com, khmansouri@hotmail.com, franck.poirier@univ.ubs.fr
}

\begin{abstract}
After launching LMD (Licence, Master, Doctorat) educational reform in 2013, the Moroccan higher education system encountered many problems and obstacles concerning the integration of information and communication technologies (ICT) in the traditional teaching methods, as tools to enable all training institutions to achieve higher level educational services, especially in a competitive mass education environment.
\end{abstract}

Several targets have been set in this direction:

- Improving continuing education of teachers using ICT.

- Modernizing teaching practices in training institutions by integrating ICT.

- Computerizing and sharing educational content with university learners.

- Raising awareness among university students on the importance of distance learning platforms through ICT.

Currently, with the provision of training and distance learning platforms such as MOOCs (Massive Open Online Courses), several trainings and online courses, in favor of learners and teachers can be proposed and organized by international training institutions and universities. Distance monitoring will improve the level, motivation and involvement of learners and teachers and therefore the feasibility and adaptability of such training in better and more adequate conditions and situations, especially the commitments of teachers.

This paper is an attempt to shed light on teachers' expectations in terms of periodic continuing education. It offers an educational business model of work, using ICT, which meets the requirements of LMD reform for the improvement of the teaching level and the teaching practices. It offers a set of management processes for the moral and material motivation of teachers, their involvement and their massive integration in on-going, periodic distance training using MOOCs. Finally, it suggests the inclusion of actual efficient and effective approaches in the use of ICT in teaching to facilitate teachers' daily work. This modeling has applications in the Moroccan educational context, especially in some large universities taken as examples for study.

Keywords: Periodic continuous training, teachers' motivation, adaptability of training, economic model, distance training, MOOC, ICT for education. 


\section{INTRODUCTION}

In recent years, the major question of the quality of higher education has become central in the Moroccan political scene and has raised much controversy. The landscape of higher education is in turmoil; the reforms have been applied continually, but the crisis in the educational sector still persists.

We must distinguish between problems of general education and the problems of higher education. The current crisis in higher education can be traced back to the problems of primary and secondary school education. To straighten the top, i.e. tertiary education, we have to solve the problems of primary and secondary education. Once this issue is settled, the level of students and raised, and the quality of training of our graduates rectified, continuity at the top will itself, with some changes in the organization and management of university structures, become smooth.

We can explain the problem of general education by:

- The diversification of educational content in the different levels of education i.e. general education (primary and secondary school), higher education, and vocational training, in both the public and the private sectors, further complicates things. These systems are completely contradictory in passing from one cycle to another. There is no continuity in the program content between different levels of training.

- The failure of human resource management in terms of the teaching and administrative staff, especially after the implementation of the strategies advanced by several political key players to ameliorate higher education and human capital development, such as:

- The Reform of Moroccan Higher Education (LMD). [1]

- Integration of ICT in higher education Morocco (Morocco Numeric2013, INJAZ Program).

- The State-Universities contract (Commitment of universities and state).

In this paper, we propose an economic pedagogy model based on current market trends after the (LMD) reform to meet the needs of human resources, especially teachers. In addition, we also offer a management plan for the motivation and involvement of teachers in their pedagogical tasks. [19]

\section{STATE OF THE ART OF UNIVERSITY TEACHERS ON-GOING TRAINING IN MOROCCO}

In this part, we present the current situation of human resource management in terms of training teachers and administrators. The two categories are interdependent. No one category can claim superiority over the other, the failure of one automatically leads to the failure of the other. Unfortunately, today, Morocco does not have the potential categories to replace the existing ones. Having teachers with the skills to be able to disseminate knowledge and educate future generations means that our university has infrastructural and educational resources to form this type of profile. However, this is not the case and it is not the university's fault. Freshmen coming to the universities either do not have the prerequisites to be successful or they are victims of a misguided choice from the start. The greatest danger of the Moroccan educational system can be traced to its inability to produce competent, specialized and motivated teachers, both in terms of quantity and quality.

For several years, the Moroccan state no longer recruits on the basis of skills and motivation as it did before. Those who choose to enter the public service as teachers do it out of necessity and not vocation or love of the profession. Moreover, the Ministry of Education has opted for direct recruitment for several years, by hiring teachers who joined the teaching profession without the required qualifications and without any pedagogical training. This step had quite negative repercussions on the quality of education at the university.

Teachers should be selected according to their skills, their level of education and their motivation and love of the teaching profession. [11] They must be trained in specialized training centers using the most effective methodologies and new teaching approaches. These teachers must receive ongoing and periodic trainings [17] [5] to be able to update and improve their course materials and their methodology, which would go hand in hand with the ultimate goal of the LMD reform. 
The administrative and managerial staff are also recruited through an accumulation system of points (inspectors grades and seniority). Those lucky enough to be chosen for this mission of administration or management are usually quite old and tired as a result of their long years in the teaching or administrative jobs, lagging far behind in ICT and aspire only for rest/retirement. We propose continuous and periodic training on information systems (IS) to properly train young managers and administrative staff for schools.

\section{GENERAL QUESTION FOR RESEARCH}

\subsection{The Moroccan Higher Education Reform (LMD system)}

Among the solutions taken by the Moroccan state to address the major problems of higher education is the reform of the educational system, which started during the 2003-2004 academic year. It is based on a fundamental change in the program structures, educational practices and evaluation system.

The main causes for this change are:

- The low success rate;

- The fact that $50 \%$ of students leave university without a degree;

- The training system was based on the passive transmission of knowledge oriented towards final exams and did not promote the development of analysis and synthesis.

The solutions proposed in the context of the educational reform face the challenge of improving the level of students and promoting success at the university by the implementation of:

- A new educational architecture (LMD);

- New learning and assessment practices;

- Training all students, regardless of option, in languages, ICT, techniques of expression and communication and methodology.

The integration of ICT in education is considered an important factor in promoting success and avoiding failure.

The development of ICT skills is identified as a transversal competence to be built and used by the student as part of the activities in various subjects of the curriculum. [3]

Some of the objectives of the integration of ICT in teaching and learning as part of the educational reform are to:

- Modernize the educational practices in training institutions,

- Communicate, inform, search and collaborate remotely, anytime,

- Keep track of one's learning,

- Organize more independently one's homework,

- Benefit from a stimulating digital learning environment,

- Connect to a library and a media library on a global level. [2]

\subsection{Problems of on-going education for Moroccan teachers.}

Other problems and barriers for higher education in Morocco in the establishment of a teacher training in the best conditions include among other variables such as, the availability, involvement and motivation of teachers, the suitability of the training, the monitoring of continuous and periodic trainings and especially the difficulty, if not the impossibility, of physical attendance during continuous trainings.

Today, and with the provision of training and distance learning platforms, based on online courses such as MOOC (Massive Open Online Courses) [6], in favor of teachers, can be proposed and organized by educational institutions (schools, universities, institutions, etc.). The Remote monitoring 
aspect of these courses can enhance the level, the motivation and the involvement of teachers and, therefore, the feasibility and adaptability of such trainings to various teacher situations and in better and more adequate conditions.

To support the use of MOOC by Moroccan teachers, the government has launched several projects to motivate the entire administrative staff, teachers and university students, especially INJAZ project (INJAZ Al-Maghrib), which is based on the acquisition of laptops and modems for quite low prices, and a free broadband connection for a year. We can also cite the MARWAN project (Morocco Wide Area Network) to interconnect all the Moroccan universities and educational institutions; the GENIE project (Generalization of ICTs in Education 2009-2013) [8], the proposed financing of all integrations of educational platforms in all universities and Moroccan educational institutions and finally the spread of broadband internet access in all rooms, corridors and halls in all Moroccan universities.

For the purposes of on-going and periodic trainings, whereby teachers' attendance is necessary, large budgets are allocated by the government. But the major problem encountered is that in general teachers encounter many obstacles to attend these trainings. These obstacles include among others:

- Time constraints: teachers do not have enough time to travel in order to attend these trainings,

- Content Problems: most of these trainings, whereby attendance is obligatory, are based on content that is not always updated,

- Problem of content adaptation: at times, the training offered does not match the teachers' real needs and does not respect their levels and skills,

- Traceability Problem: the lack of year-to-year follow-ups and gradation of these continuous and periodic trainings.

- The Training Evaluation Problem.

Following the requirements of the LMD reform and techno modern teaching approaches, such as the use of ICT in teacher training, we offer an information system (IS) [13] [12] capable of managing and effectively monitoring and tracking continuing education offered in favor of Moroccan teachers.

\section{PROPOSAL OF AN ECONOMIC PEDAGOGY MODEL FOR TEACHER TRAINING}

In this section, we offer a pedagogical plan using MOOC for teacher training [4]. MOOC platforms offer updated content, well adapted to the level, the specialty and type of course (theoretical course, tutorial or practical work). Some details about some MOOC platforms are considered in Table 1 bellow:

Table 1: Some details of the MOOC

\begin{tabular}{|l|l|l|l|l|}
\hline MOOC Platform & Learners level & Type of course & \multicolumn{1}{|c|}{ Specialty } & \multicolumn{1}{|c|}{$\begin{array}{l}\text { Institution } \\
\text { partners }\end{array}$} \\
\hline Coursera & $\begin{array}{l}\text { Intermediate and } \\
\text { expert }\end{array}$ & $\begin{array}{l}\text { All types of } \\
\text { courses }\end{array}$ & $\begin{array}{l}\text { All course } \\
\text { categories }\end{array}$ & $\begin{array}{l}\text { University : } \\
\text { Edimbourg, of } \\
\text { Amsterdam, } \\
\text { Colorado à } \\
\text { Boulder }\end{array}$ \\
\hline Edx & $\begin{array}{l}\text { Beginner, } \\
\text { intermediate and } \\
\text { expert }\end{array}$ & $\begin{array}{l}\text { All types of } \\
\text { courses }\end{array}$ & $\begin{array}{l}\text { All course } \\
\text { categories }\end{array}$ & $\begin{array}{l}\text { MIT, Harvard } \\
\text { University, } \\
\text { Berkeley } \\
\text { University of } \\
\text { California }\end{array}$ \\
\hline FUN & $\begin{array}{l}\text { Beginner and } \\
\text { intermediate }\end{array}$ & $\begin{array}{l}\text { All types of } \\
\text { courses } \\
\text { University of } \\
\text { Bordeaux, Institut } \\
\text { des Mines- } \\
\text { Télécoms }\end{array}$ \\
\hline
\end{tabular}




\begin{tabular}{|l|l|l|l|l|}
\hline Openclassroom & $\begin{array}{l}\text { Beginner, } \\
\text { intermediate and } \\
\text { expert }\end{array}$ & $\begin{array}{l}\text { Lectures, tutorials } \\
\text { and practicals in } \\
\text { computer }\end{array}$ & Computer science & $\begin{array}{l}\text { Paris School of } \\
\text { business, } \\
\text { ENSAE-ENSAI, } \\
\text { Intech }\end{array}$ \\
\hline Khan Academy & $\begin{array}{l}\text { Beginner, } \\
\text { intermediate and } \\
\text { expert }\end{array}$ & TD Math & Mathematics & \\
\hline $\begin{array}{l}\text { ABC Gestion de } \\
\text { Projet }\end{array}$ & Expert & $\begin{array}{l}\text { Lectures, tutorials } \\
\text { and practicals in } \\
\text { Project } \\
\text { Management }\end{array}$ & $\begin{array}{l}\text { Management and } \\
\text { Project } \\
\text { Management }\end{array}$ & $\begin{array}{l}\text { Ecole centrale de } \\
\text { Lille }\end{array}$ \\
\hline
\end{tabular}

The MOOC platforms, in Table 1, are $\mathrm{XMOOC}$ (transmissive) MOOC [7], that is to say, they use the same educational approaches as the traditional face-to-face system, and their educational content is made of videos, documents, tutorials, quizzes and of practical workshops. Teachers are encouraged to use these platforms for self-training, in function of their specialty, level and type of course, to improve the educational content of their courses and to benefit from new experiences of other teachers on a global scale.

Our pedagogical teacher-training plan is as follows:

- For teachers of modules in relation or closer to project management, planning, project management diagrams and flowcharts, production management, we assume that the most suitable MOOC platform would be the MOOC ABC project management. This platform is animated by the best teachers in Lille center school and supervised by Professor Rémi Bachelet [15]. It is a project management-oriented MOOC.

- For teachers of modules such as mathematics, statistics and operational research, we feel that the Khan Academy MOOC, specialized in preparing students for math exams, is the most appropriate for these scientific modules.

- For teachers of computer modules, we offer Openclassroom, distance-learning platform that provides these learners (students and teachers) with in step-by-step web-oriented tutorials. It also contains general IT and business management modules. This MOOC platform is the European leader in the field of programming and computer web.

- For teachers of other general modules we suggest the Coursera MOOC, Edx and FUN that offer digital-rich content to learners, for any type and category of course. They are of a more general nature.

All these MOOCs offer courses, follow-ups and current resources for the benefit of learners (students and teachers), which are disseminated by the best schools in the world. This is a precious opportunity for self-training and on-going education for Moroccan teachers. [18]

\section{PROPOSAL OF A MANAGEMENT PLAN FOR THE MOTIVATION OF TEACHERS IN TRAINING.}

To better benefit from the MOOC novelty and reliability, presented above, under the form of tools and resources for ongoing training, we invite teachers to:

- Attend regular periodic trainings on these learning platforms to update their teaching content,

- Share, continuously and permanently, their knowledge and experience with teachers from around the world,

- Improve their educational content by exploiting the digital content disseminated by the best universities in the world,

- Educate students on free international learning platforms such as MOOC (Massive Open Online Course)

- Interact with learners when using online courses (emails, forums and discussions via social networks)

- Have supporting documentation for training from officials, such as MOOC certificates, badges and, of course, participation certificates [16]. 
- Ensure Traceability of control and monitoring by training teachers on MOOC. To do so, we provide a good information system that will provide and manage these operations.

The MOOCs also offer ways for motivating learners, such as certificates, badges, certificates of participation and free membership in some new modules.

In conclusion, teachers are encouraged to apply, share and experience the key input obtained from the MOOC in their daily work with students, with the ultimate aim of improving the Moroccan educational system, which, in turn, must incorporate information technology and communication for education (ICTE) to good use. [9]

\section{CONCLUSION AND PERSPECTIVE}

We proposed continuous and periodic training for the benefit of teachers as self-study via MOOC, in order to face the problems of lack of time and the difficulty to attend face-to-face trainings.

We also advanced an educational plan based on the use of MOOC by specialty, level and type. In the end, we mentioned a set of benefits and managerial processes for motivating teachers to take distance learning. [10] [16]

In conclusion, we propose a reform in on-going education and distance learning for the benefit of teachers, and an integration of MOOC in the Moroccan educational system [14] by expert teachers in the field.

\section{REFERENCES}

[1] A. Aamili, A. Chiadli « La formation des formateurs en TIC au Maroc : quelles stratégies ? ", 4e ouvrage du RIFEFF, Bibliothèque et Archives Canada, 2012.

[2] A. Benchenna «L'appui de la France à la Rérofme de l'Enseignement supérieur (ES) au Maroc : quelles finalités et quels enjeux ? », JHEA/RESA Vol. 7, Nos. 1\&2, 2009, pp. 121-140

[3] A. Ghouati "Réforme LMD au Maghreb: éléments pour un premier bilan politique et pédagogique », JHEA/RESA Vol. 7, Nos. 1\&2, 2009, pp. 61-77

[4] Cisel, M. Bruillard, E. «Chronique des MOOC, Sciences et Technologies de I'Information et de la Communication pour l'Éducation et la Formation», Vol. 19, http://sticef.univlemans.fr/num/vol2012/13r-cisel/sticef_2012_cisel_13r.htm, 2012

[5] G. Temperman, D. Lucas et B. De Lièvre, «Appropriation réflexive des modalités d'usage du tableau noir par des enseignant(e)s en formation initiale », Questions Vives [En ligne], $N^{\circ} 24$ 2015, URL : http:// questionsvives.revues.org/1835 ; DOI : 10.4000/questionsvives.1835, mis en ligne le 15 février 2016, consulté le 24 août 2016.

[6] I. Nawrot and A. Doucet « Building Engagement for MOOC Students - Introducing Supprot for Time Management on Online Learning Platforms ", communication dans un congrès WWW'2014.

[7] J.C. Pomerol Yves Epelboin Claire Thoury «Les MOOC Conception, usages, et modèles économiques » ISBN 978-2-10-071283-0DUNOD, les pages 11, 12 et 13, Paris 2014

[8] Kabbaj, M. Talbi, M. Drissi My, M. Abouhanifa, S. «Programme GENIE au Maroc : TICE et développement professionnel.» Mathématice. $\mathrm{N}^{\circ}$ 16. Septembre. En ligne http://revue.sesamath.net/spip.php?article233, 2009

[9] L. Trouche «Les recherches francophones en TICE dans le pourtour sud de la Méditerranée ", rapport d'étude financé par l'IFIC (Institut de la francophonie pour l'ingénierie de la connaissance et la formation à distance), soutenu par l'implication des équipes de l'institut français de l'éducation (ENS de Lyon), à Lyon mars 2014.

[10] M. Khaneboubi, G.L. Baron « Analyse de la participation à un cours en ligne ouvert à tous : le cas d'« enseigner et former avec le numérique (eFAN) », RITPU volume 12, 2015

[11] M.J. Beers, J.C. Hill, C.A. Thompson, P. Tran. "Graduate training in the teaching of psychology: Essential skills for newinstructors.», ELSEVIER, ScienceDirect, 23 juin 2014. 
[12] N.Benmoussa, K. Mansouri, M. Qbadou and E. Illoussamen, "Vers une solution de prise de décision à travers un système expert pour l'optimisation et la planification des formations continues des ressources humaines des universités marocaines », Congrès AMAQUEN, 2016.

[13] P. GERMAK and J.P. MARCA « Management des systèmes d'information », Manuel and applications, Editions Sup' FOUCHER, 2007/2008.

[14] S. Delpeyroux, R. Bachelet. «Intégrer un MOOC dans un cursus de formation initiale. Colloque Questions de Pédagogie dans l'Enseignement Supérieur (QPES) 2015. http://www.colloquepedagogie.org/, Jun 2015

[15] S. Delpeyroux, R. Bachelet. «Intégrer un MOOC dans un cursus de formation initiale. Colloque Questions de Pédagogie dans l'Enseignement Supérieur (QPES)» 2015, Jun 2015, Brest, France. 2015, Actes du Colloque Questions de Pédagogie dans l'Enseignement Supérieur (QPES) 2015. http ://www.colloque-pedagogie.org/.

[16] S. Zheng, M. Beth Rosson, Patrick C. Shih, and J.M. Carroll «Understanding Student Motivation, Behaviors, and Perceptions in MOOCs», CSCW 2015, March 14-18, Vancouver, BC, Canada, 2015

[17] T. Chanier, J. Cartier « Communauté d'apprentissage et communauté de pratique en ligne : le processus réflexif dans la formation des formateurs », Revue Internationale des Technologies en Pédagogie Universitaire, Conférence des recteurs et principaux des universités du Québec [CREPUQ], 3 (3), pp.64-82. http: //www.profetic.org/revue//MG/pdf/cartier.pdf, 2006

[18] T. Karsenti «MOOC Révolution ou simple effet de monde», publication dans une revue internationale, Revue internationale des technologies en pédagogie universitaire, 10(2), www.ritpu.org, 2013

[19] T. Karsenti, "Trois stratégies pour favoriser l'engagement des participants à un MOOC ", Université de Montréal, CANADA, RITPU volume 12, 2015 